\title{
Um homem plural e seu(s) tempo(s): revisitando Nabuco e as controvérsias em torno a Minha Formação
}

\author{
Gabriel Peters*
}

Resumo: Como uma contribuição aos debates propiciados pelas comemorações do centenário do falecimento de Joaquim Nabuco, o ensaio revisita livremente alguns dos temas centrais de Minha Formação, obra clássica em que o autor reconstroi o percurso experiencial que desembocou na constituição de sua Weltanschauung madura - monarquista, católica e "apolínea" (Freyre). Dialogando seletivamente com a pluralidade de leituras sobre o homem e seu tempo no pensamento social brasileiro, o texto acompanha como Nabuco costura os vínculos entre, de um lado, as peripécias biográficas que emolduraram sua personalidade e, de outro, os dilemas políticoculturais que marcaram sua época e dos quais ele foi tanto personagem de proa quanto observador arguto.

Palavras-chave: Joaquim Nabuco; Minha Formação; personalidade; biografia e história

Abstract: As a contribution to the debates sparkled by the commemorations of the centennial of Joaquim Nabuco's death, the essays freely revisits some of the central themes of Minha Formação, the classical work in which the author reconstructs the experiential path that culminated in his mature Weltanschauung - monarchist, catholic and "apollonian" (Freyre). Selectively engaging with the plurality of readings about the man and his time, the text traces how Nabuco forges the links between the biographical adventures that framed his personality, on the hand, and the culturalpolitical dilemmas that marked his age, dilemmas regarding which he was both an eminent character and an acute observer.

Keywords: Joaquim Nabuco; My Formation; personality; biography and history

Minha Formação, frequentemente elencada dentre as primeiras obras do gênero autobiográfico nas letras tupiniquins, consiste, ainda assim, em um espécime singular de autobiografia. Nela, Joaquim Nabuco está particularmente ocupado com a apresentação das fontes experienciais de algumas das suas mais importantes ideias estéticas e políticas (sua "formação político-literária ou literário-política"), bem como

\footnotetext{
* Mestre em Sociologia pela Universidade de Brasília (UnB) e Doutorando em Sociologia pelo Instituto Universitário de Pesquisas do Rio de Janeiro (IUPERJ).

Endereço eletrônico: gabrielpeters@hotmail.com
}

Latitude, vol. 4, nํㅡ 2, pp. 67-89, 2010

DOI: https://doi.org/10.28998/2179-5428.20100205 
Um homem plural e seu(s) tempo(s): revisitando Nabuco e as controvérsias em torno a Minha Formação

éticas e religiosas (sua "formação humana"), ideias tais como a defesa da monarquia constitucional de feitio britânico contra o republicanismo de estirpe francesa ou estadunidense, o compromisso com o ideal abolicionista ou ainda o catolicismo, esta "perspectiva final do mundo mais bela e radiante" (p.28) à qual o autor se reconverteu tardiamente ${ }^{1}$.

Nessa recuperação das vivências subjacentes à formação de sua Weltanschauung madura, em que um elogio da serenidade psicológica caminha pari passu com uma apologia antijacobinista da estabilidade político-institucional, Nabuco confere um papel especial às suas viagens à Europa e aos Estados Unidos, perfazendo um relato biográfico que é também oportunidade para o desenvolvimento de uma rica sociologia política e cultural comparativa ${ }^{2}$. Vale dizer, no entanto, que a reflexão nabuquiana sobre as diferentes sociedades e regimes políticos que ele pôde observar in situ, em suas jornadas pelo exterior, é sempre referida, ainda que muitas vezes apenas implicitamente, à realidade brasileira, tanto no que tange à recém-finda experiência imperial, quanto no que respeita aos problemas trazidos no bojo da recém-estabelecida república. Assim, por exemplo, os elogios que faz à monarquia parlamentar inglesa por sua capacidade de combinar o respeito às tradições e à estabilidade com o compromisso reformista de aprimoramento contínuo do regime desemboca no próprio elogio à tradição reformista do Império no Brasil, enquanto, por outro lado, a crítica

\footnotetext{
${ }^{1}$ As páginas referidas nas citações de Minha Formação são sempre da edição publicada pelo Senado Federal em 1998 (ver Nabuco, 1998b).

2 Poderíamos falar mesmo de uma sociologia político-cultural, posto que a obra do pensador brasileiro partilha com a de seu herói monarquista Bagehot uma preocupação central com o problema da articulação entre "a legitimação das formas de governo" e a "existência de determinadas condições culturais" (Carvalho, 2001: 226). No que diz respeito à natureza específica da inteligência do social em Nabuco, podemos dizer, com Evaldo Cabral de Mello (2005: 85), que ela prima mais pela "intuição sociológica" - o senso aguçado de observação "etnográfica" - do que pela "formação sociológica" - a aplicação sistemática de perspectivas sócio-teóricas à compreensão de realidades específicas. Entretanto, tal fato estaria longe de ser uma desvantagem intelectual na avaliação de Mello. Segundo este, textos como O Abolicionismo conservam sua atualidade precisamente por passarem, em grande medida, ao largo "do que se julgava no Brasil serem as últimas tendências da sociologia europeia" (Mello, 2000: 7) no final do século XIX, enquanto obras historiográficas como Os Sertões, de Euclides da Cunha, este fortemente informado pelas teorias sociológicas hegemônicas à época (e.g, o pensamento de Buckle, impregnado de supostos sobre a desigualdade inata das raças), acabaram, até certo ponto, envelhecendo juntamente com o ferramental teórico que lhes servira de suporte. Nesse sentido, podemos dizer que o contextualismo ou "espírito de realidade" (p.121) defendido por Nabuco em política, segundo o qual a atividade política deve partir das particularidades de uma determinada situação histórica e não da tentativa de materializar forçosamente princípios abstratos, está presente também, em versão epistemológica, no seu trabalho de historiador.
} 
Gabriel Peters

correlata ao "fermento de ódio" e à "intolerância...do republicanismo agressivo francês" (p.61-62) é explicitamente associada ao reconhecimento da sua influência perniciosa sobre os republicanos brasileiros. Ergo, embora Nabuco não discuta a fundo os eventos políticos no Brasil dos anos 1890 e chegue a dizer, no prefácio da obra, que a política não fora "sua impressão dominante ao traçar estas reminiscências" (p.28), pelo menos uma parte bastante substancial de Minha Formação pode ser lida, de fato, como "uma peça de persuasão política"3 (Carvalho, 2001:227).

Além disso, como Nabuco é figura de proa não apenas na historiografia, mas também na história de seu tempo, a evocação de suas impressões de viajante configura em si mesma um documento valioso de "histoire des mentalités", ao registrar como uma subjetividade particularmente sensível experimentava o "dilema do mazombo" (Mello, 2000: 26), uma divisão íntima, muito comum dentre os membros da elite brasileira nos finais de Oitocentos (sobretudo nas fileiras da intelligentsia), entre a atração da "imaginação" pela Europa e a atração do "sentimento" pelo país (p. 59).

Se, como afirmou C.Whright Mills (1975), a habilidade central da "imaginação sociológica" consiste na intelecção das complexas articulações entre percursos biográficos particulares e processos sócio-históricos mais amplos, o trabalho de Nabuco é dos mais relevantes para a compreensão sociológica da história do Brasil das últimas décadas do século XIX, vista, por assim dizer, "a partir de dentro", isto é, sob o prisma agudamente perceptivo de um dos principais atores no cenário político e cultural da época. O livro, aliás, não constitui o único exemplar da extraordinária habilidade de Nabuco em capturar os vínculos entre trajetórias biográficas específicas

${ }^{3}$ A aparente contradição entre o prefácio e os demais capítulos provavelmente se deve ao fato de que o primeiro foi escrito em 1900, sendo o livro, no entanto, uma reunião de textos escritos entre 1893 e 1899. Dessa forma, pelo menos se nos fiarmos pelo que diz o próprio Nabuco, o prefácio já exprimia um estado de espírito em que havia enfraquecido "o interesse" e "a sedução política". Com efeito, precisamente por expressar "idéias, modos de ver, estados de espírito" (p.27) dos diferentes momentos em que seus capítulos foram escritos, o percurso de Minha Formação permite visualizar a própria mudança interior de prioridades existenciais em função da qual o autor se sente gradativamente menos instado a discutir as experiências políticas e estéticas que lhe levaram a abraçar a defesa da monarquia parlamentarista, em favor de uma concentração sobre sua "formação humana", onde dá destaque às suas vivências de infância no engenho pernambucano de Massangana, um "paraíso perdido" onde foi despertado, por outro lado, seu sentimento de compaixão para com o sofrimento dos escravos, a fonte primeira da sua luta abolicionista. Como ele informa no capítulo que tem o nome do velho engenho: “ A razão que me fez não começar pelos anos de infância foi que estas páginas tiveram, ao ser primeiro publicadas, feição política que foram gradualmente perdendo, porque ao escrevê-las diminuía para mim o interesse, a sedução política. A primeira ideia fora contar minha formação monárquica; depois, alargando o assunto, minha formação político-literária ou literário-política; por último, desenvolvendo-se sempre, minha formação humana, de modo que o livro confinasse com outro, que eu havia escrito antes, sobre minha reversão religiosa" (p.179).

Latitude, vol. 4, nํㅡㄹ pp. 67-89, 2010. 
Um homem plural e seu(s) tempo(s): revisitando Nabuco e as controvérsias em torno a Minha Formação

e transformações sócio-históricas mais abrangentes. No hoje clássico Um Estadista do Império (1998a), Joaquim Nabuco desenha uma biografia de seu pai, o Conselheiro e Senador José Thomaz Nabuco de Araújo. Seguindo o modelo anglo-saxão life and times (Mello, 2000:21), aquele utiliza a trajetória deste como mote para fornecer um perspicaz painel de boa parte da história da política imperial oitocentista, painel singularmente penetrante no que tange ao traçado dos perfis psicológicos dos estadistas do período, como Eusébio de Queirós, Zacarias e Rio Branco.

Tal como Um Estadista no Império, Minha Formação só veio a lume devido a uma espécie de transformação existencial vivida por Nabuco ao longo dos anos 1890, pouco após a abolição da escravatura, pela qual ele tanto havia lutado, e o subsequente colapso da monarquia. Decepcionado com a débâcle do regime ao qual ele, como André Rebouças, era tão grato por seu papel no sucesso da causa abolicionista, Nabuco opta pelo ostracismo e dedica-se com vigor às atividades de memorialista e historiador ${ }^{4}$. $\mathrm{O}$ livro constitui um dos mais brilhantes produtos desta fase em que Nabuco, após anos de intensa experimentação estética, perambulação geográfico-cultural e atividade política que gastaram a "violência" da sua mocidade, goza (goethianamente) do repouso e tranquilidade espiritual da maturidade no "retraimento do mundo" e mergulha em um esforço de resgate do passado imperial e contemplação da própria trajetória.

\footnotetext{
${ }^{4}$ Afirmamos anteriormente que Nabuco alcançou um status raro ao se fazer personagem central e, ao mesmo tempo, historiador arguto de sua época. No entanto, como lembra Evado Cabral de Mello, para quem Um Estadista do Império constitui "uma das cinco ou seis obras cimeiras da historiografia nacional" (2005: 17), é óbvio que ele não poderia ter tardiamente colocado em prática o conselho renaniano de devotar-se a estudos históricos (p.88) não fosse pelo seu "retraimento forçado" (p.28) em face da cena política republicana: "O caso de Nabuco é sintomático de que não há nada melhor do que um bom ostracismo à produção intelectual do indivíduo permanentemente dilacerado entre a atração da atividade política e a da reflexão. Os anos 80...haviam sido demasiado participantes (salvo pelo breve interlúdio londrino em que escreveu O Abolicionismo) para que ele pudesse se dar ao luxo da meditação ou de sequer escrever os Diários. Daí que datem dos anos 90 as grandes obras que iriam consagrá-lo como escritor e historiador" (Mello, Op.cit: 15). Dizendo o mesmo de maneira mais concisa, Graça Aranha afirmou espirituosamente sobre Nabuco que " $a$ abolição também deu-lhe a liberdade" (Aranha, 1942: 246). Segundo o homem mesmo, o termo de sua carreira política foi também condição fundamental do retour en force de suas indagações religiosas: "Enquanto a luta contra a escravidão durasse, penso que a religião não sairia para mim do estado latente de ação humanitária. Muitas vezes mesmo, a religião não consegue desprender-se da tarefa da vida, e é somente quando essa tarefa se acaba ou se interrompe que as perquirições interiores começam, que se quer penetrar o mistério, que se sente a necessidade de uma crença que explique a vida. (...)A ação é uma distração. É só acabada ela que em certa ordem espíritos as afinidades superiores se pronunciam" (p.227).
} 
Gabriel Peters

Dispostos linearmente, os momentos fundamentais da vida de Nabuco rememorados na obra são:

a) a infância no engenho pernambucano de Massangana - evocada no antológico capítulo de mesmo título (originalmente escrito para constar no livro mais intimista sobre sua reversão religiosa: Foi Volue). Naquele engenho, Nabuco havia sido, até os oito anos, amorosamente criado por sua madrinha Ana Rosa Falcão de Carvalho, respirando desde cedo o ar da religiosidade e vendo também emergir em si "o interesse pelo escravo" (p.178);

b) após o falecimento da madrinha, a mudança para o Rio de Janeiro e os primeiros contatos com o pai, dos quais adveio, ainda que de um modo mais indireto e sentimental ("por meio dos melhores impulsos do coração" [p.161]), "o fundo hereditário" do seu liberalismo (p.31);

c) os anos como estudante de direito em São Paulo e Recife, caracterizados pela avidez com que devorava livros e era arrebatado por igual pelas mais diversas ideias ("posso dizer que não tinha ideia alguma, porque tinha todas" [p.34]), bem como pelo enfraquecimento de sua fé católica até então "virgem" e pela intensa oscilação entre a adesão ao monarquismo ou ao republicanismo, ao qual quase "sucumbiu" em seus momentos mais radicais;

d) a primeira viagem à Europa, também vivida em um espírito de impressionabilidade febril e inconstante diante de cada "nova fascinação da arte, da natureza, da literatura e, também, da política" (p.57), impressionabilidade que só seria vencida na sua chegada a Londres, onde "a curiosidade de peregrinar" foi substituída pelo "desejo de parar ali para sempre" (p.98);

e) o período como adido de legação nos Estados Unidos, onde tem a oportunidade de observar os acontecimentos do cenário político americano, que só lhe fazem confirmar sua predileção pela monarquia parlamentar à inglesa;

f) após a morte de seu pai em 1879, o encerramento de seu período de "lazaronismo intelectual" (p.173), em que as preocupações estéticas (inclusive os malfadados esforços como poeta, sobre os quais Nabuco foi retrospectivamente tão sincero) haviam predominado sobre as políticas ${ }^{5}$. É nesse momento que se dá sua entrada no parlamento brasileiro como deputado geral, sob pressão de sua mãe, e o engajamento na campanha abolicionista, sua principal (e, em última instância, única) bandeira durante os tempos de político;

${ }^{5}$ Um registro da hegemonia da "mola estética" do espírito de Nabuco nessa fase de sua existência encontra-se no que ele escreve em seu diário, em 16 de maio de 1877: "A única coisa de que verdadeiramente eu nunca duvido é do belo. (...)O belo é a única coisa que não admite ceticismo" (2005a: 152).

Latitude, vol. 4, no 2, pp. 67-89, 2010. 
Um homem plural e seu(s) tempo(s): revisitando Nabuco e as controvérsias em torno a Minha Formação

g) o ostracismo forçado após a queda da monarquia logo em seguida à abolição, um período marcado pela dedicação à atividade memorialística e historiográfica, bem como pelo reencontro maduro com o cristianismo ${ }^{6}$.

No que se segue, não tenho como desenvolver uma análise detalhada do opus de Nabuco ou de sua fortuna crítica, mas apenas uma apreciação seletiva de algumas das ideias fundamentais contidas nesta peça chave do pensamento social brasileiro, vazadas naquela prazerosa forma ensaística que marca os trabalhos de tantos outros luminares da interpretação do Brasil.

\section{A monarquia e a república}

Em setembro de 1890, de saída para o que seria um curto exílio voluntário em Londres, Nabuco publicou no Diário do Comércio um texto intitulado "Por que continuo monarquista" (Alonso, 2007: 249). Um conjunto considerável de capítulos de Minha Formação poderia ser agrupado sob o título de "Como me tornei monarquista". Dentre estes, vale ressaltar aquele em que o autor se dedica à apresentação da pequena obra de Bagehot A constituição inglesa, um livro que, ao revelar "as molas ocultas" (p.39) do sistema político inglês, teria garantido "sua fixação monárquica inalterável", fornecendo "a ferramenta" com a qual ele trabalharia em política (p.35). Na realidade, como o próprio Nabuco explica ao longo dos demais capítulos, as coisas não foram tão simples assim. Dois anos após a leitura de Bagehot, o jornalista moço escreve um artigo "quase republicano" sobre a viagem de Dom Pedro II à Europa em que descreve o aparato monárquico como "luxo" e "superfetação", sugerindo ao imperador que fosse aos Estados Unidos, visto por ele como vanguarda do "progresso industrial e moral"7 (p.49). A adesão definitiva à monarquia viria, segundo Nabuco, somente em 1873, embora ele confesse que a verdadeira compreensão da validez dos ensinamentos de Bagehot tenha advindo apenas no momento em que ele pôde constatar in loco o quanto o retrato bagehotiano do regime inglês correspondia à realidade:

\footnotetext{
${ }^{6}$ A fé da sua infância foi redespertada na sua segunda estada em Londres, em um período de sofrimento pessoal e dificuldades financeiras, primeiramente aos "açoites do padre Gallwey..na escondida igreja dos jesuítas em Farm Street" e posteriormente "no oratório de Brompton" (p.104). A crença e o sentimento religiosos acompanharam Nabuco até sua morte, mas seu ostracismo, por outro lado, foi passageiro. Já em 1899, ele foi encarregado pelo governo brasileiro da defesa, perante representantes da Itália (escolhida como país árbitro), dos direitos do Brasil na questão dos limites da Guiana Inglesa, tornando-se posteriormente embaixador do Brasil em Washington, onde veio a falecer em 1910.

7 O Nabuco de Minha Formação certamente continua situando os E.U.A na vanguarda do desenvolvimento industrial, mas sustenta - indo de um extremo a outro, segundo Gilberto Freyre (p.12) - que o país não tinha "o que mostrar...na ordem intelectual e moral" (p.142).
} 
“...não fiz na Inglaterra senão verificar por mim mesmo a precisão, a penetração, a agudeza de espírito de Bagehot. O seu pequeno livro, cotejado com o que eu via, ouvia e sabia, explicavase, tornava-se claro...; fazia-me compreender o mecanismo de que ele formulara a teoria"8 (p.115).

A articulação entre reformismo e estabilidade, espírito de progresso e espírito de tradição, não constitui para Nabuco simplesmente um objeto de doutrina filosóficopolítica, mas uma conquista histórica da Inglaterra, uma experiência real que parece paradoxal à luz de ideários morais abstratos (p.39). Do ponto de vista da eficácia administrativa, a vantagem da monarquia parlamentar inglesa estaria na fusão dos poderes legislativo e executivo no chamado governo de gabinete. Em princípio, o legislativo comporia o executivo com os quadros julgados mais apropriados para a condução "da parte prática dos negócios" (p.40), podendo modificá-los conforme a avaliação da sua competência. Isto não provocaria uma subordinação do executivo ao legislativo, na medida em que o primeiro seria dotado da prerrogativa de "fazer a legislatura comparecer perante os eleitores, para que estes lhe componham uma Câmara mais favorável às suas ideias" (idem). Esse expediente impediria o arrastar dos eventuais conflitos entre os dois poderes, diferentemente do que acontece no regime presidencial, onde a independência mútua entre legislativo e executivo gera confrontos que podem se estender pelos períodos fixos de exercício dos mandatos.

O regime monárquico possuiria, assim, uma elasticidade que lhe permitiria um enfrentamento mais eficiente dos problemas de governo, sendo também mais suscetível ao controle contínuo pela opinião pública, que se tornaria por isso mais interessada no transcorrer dos debates legislativos, exercendo uma pressão que faria da assembleia legislativa um "magnífico teatro para os debates", uma "escola de instrução popular e controvérsia política" (p.42). No governo presidencial, por contraste, estando a influência da população reduzida, grosso modo, à participação

${ }^{8}$ Para acompanhar esse cotejamento, me parece produtivo ler os capítulos A influência inglesa e $O$ espírito inglês em seguida ao Bagehot. Assim como julgou obter a confirmação empírica ou experiencial das virtudes do sistema monárquico na sua estadia na Inglaterra, Nabuco também substanciou a crítica abstrata ao regime presidencial com uma discussão dos eventos que observou na cena política estadunidense durante o período em que lá viveu como adido de legação (ver os capítulos Nova Iorque (1876-1877), O meu diário de 1877, Traços americanos e Influência dos Estados Unidos). A monarquia parlamentar inglesa superaria o presidencialismo dos Estados Unidos no que tange à moralidade no trato com a coisa pública, na igualdade de tratamento perante o sistema judiciário, na qualidade dos debates legislativos, no senso de responsabilidade cívica do cidadão comum, etc. Diga-se, de passagem, que várias das observações de Nabuco sobre a terra de Thomas Jefferson (por exemplo, a respeito da "crueza da publicidade" a que estavam expostos todos os que se aventuravam na carreira política por lá) permanecem impressionantemente atuais.

Latitude, vol. 4, no 2, pp. 67-89, 2010. 
Um homem plural e seu(s) tempo(s): revisitando Nabuco e as controvérsias em torno a Minha Formação

periódica nas eleições, os debates legislativos não possuiriam nem a visibilidade pública nem a qualidade formativa característica do parlamentarismo monarquista.

Há ainda mais um argumento bagehotiano crucial ao pensamento político de Nabuco, qual seja, o referente ao papel simbólico e, por assim dizer, sociopsicológico exercido pelo aparato da realeza, uma classe de instituições "cerimoniais" (Spencer) cuja função seria a de produzir e conservar "o respeito das populações", garantindo que as mudanças contínuas no governo de gabinete fossem operadas sob um fundo de permanência, de "um governo não sujeito à eleição" (p.45) que manteria assim a "calma do espírito nacional" (p.44) ao longo da evolução sócio-histórica. A não eletividade dos postos mais elevados do estado protegeria o governo das "interrupções periódicas" a que estaria condenado o regime republicano, interrupções "que são para certos países revoluções certas" (p.47; e aqui Nabuco se refere obliquamente não apenas ao Brasil, mas também a outros países latinoamericanos, como o Chile). A "ferramenta" com que Nabuco trabalhará em política está, portanto, construída: a combinação entre as instituições eficientes (governo de gabinete) e as instituições imponentes (realeza) faz da monarquia parlamentar à inglesa um regime ao mesmo tempo mais democrático $e$ estável, um sistema "...mais sensível à opinião, mais rápido e mais delicado em apanhar-lhe as nuanças fugitivas, guardando ao mesmo tempo inalterável a tradição de governo e a aspiração permanente do destino nacional" (p.47).

Vale dizer, no entanto, que, embora Nabuco apresente os princípios de sua adesão monárquica como "teoremas de geometria política", ele mesmo se apressa em dizer time and again que escolhas político-ideológicas não podem ser decididas in abstracto, mas sempre no contexto de experiências e circunstâncias sócio-históricas concretas (p.116). É inclusive calcado nessa postura política contextualista, isto é, na crença de que "a forma de governo não é uma questão teórica, porém prática, relativa, de tempo e de situação" (p.73), que ele sustenta, nas suas passagens conclusivas, que sua adesão à monarquia não era inflexível e incondicional, e certamente não estava colocada acima de seu compromisso com a pátria9 $(p .240)$.

\section{A Europa, a América e o dilema dos mazombos}

Em uma passagem pungente de Pensées detachées et souvenirs, o poliglota Nabuco medita sobre nosso vocábulo "saudade":

\footnotetext{
9 Segundo Carvalho, estas afirmações conclusivas do livro já permitem entrever a disposição de Nabuco em retornar à vida pública, acorrendo "a um eventual chamamento do país" (Carvalho, 2001: 221). A tese de que a fidelidade à pátria tem de estar acima da "vassalagem ao princípio monárquico" (p.240) é tida por Nabuco como princípio-guia dos melhores políticos imperiais (seu pai, dentre eles).
} 
Gabriel Peters

"Entre todos os vocábulos não deve haver nenhum tão comovente quanto a palavra portuguesa saudade. Ela traduz a lástima da ausência, a tristeza das separações, toda a escala de privação de entes ou de objetos amados; é a palavra que se grava sobre os túmulos, a mensagem que se envia aos parentes, aos amigos. É o sentimento que o exilado tem pela pátria" (apud Santiago, 2004: 20).

O memorialismo de Nabuco se confessa guiado pelo sentimento de saudade em diversos momentos do livro: do pai ${ }^{10}$, da vida em Massangana, de sua madrinha, dos escravos (não da escravidão), do Império. Se nos fiarmos pela sua definição e concebermos a saudade de modo mais genérico como "lástima da ausência" (que inclui a nostalgia do passado, mas não se reduz a ela), podemos ver tal sentimento como uma presença contínua na vida interior de Nabuco, particularmente como o motor subjetivo das suas frequentes viagens transatlânticas. A "lástima da ausência" constitui o elemento central na vivência do dilema do mazombo: ausência de história e cultura quando do lado de cá, ausência do país a que se está afetivamente ligado quando do lado de lá.

10 Em relação ao pensamento de seu pai, Nabuco diz ter passado da admiração e do assentimento ingênuo e "instintivo" (p.170) na infância a uma postura de rebeldia e independência na mocidade, chegando finalmente, após o necessário "crescimento e amadurecimento do espírito" (p.161), a uma fase de assentimento esclarecido e de "admiração consciente, objetiva" (p.170), a fase em que se ele encontra quando escreve as linhas de Minha Formação. No capítulo "Meu Pai", após reiterar a intuição que desde cedo teve da sua "superioridade", manifesta na "harmonia visível de sua estrutura mental e moral" (p.168), ele confessa só haver podido abarcar a personalidade e o gênio político do monarquista liberal Nabuco de Araújo bem após a sua morte. O espírito de realidade que ele havia elogiado na monarquia parlamentar teria sido também o valor nuclear da atuação política do seu pai, que preferia as conquistas concretas aos "fantasmas", o "bem estar relativo" aos "grandes direitos ilusórios", seguindo uma conduta pautada por aquilo que Weber denominaria alguns anos depois de "ética da responsabilidade": "Essa era sua qualidade principal de político: adaptar os meios aos fins e não deixar periclitar o interesse social maior por causa de uma doutrina ou aspiração" (p.164-65). É também no capítulo sobre seu pai que Nabuco produz algumas das passagens mais intimistas (e emocionantes) do livro, ao confessar que o desejo de mergulhar nos detalhes de seu modo de ver e pensar o mundo teria vindo tarde demais: "Este desejo de recolher os menores vestígios de seu pensamento, os traços mais fugitivos da sua reflexão..só me veio quando já não podia recorrer a ele, pedir-lhe esclarecimentos, fazê-lo animar para mim aquela poeira com a vida que estava só nele (...)Por que não fiz passar diante dele... a galeria dos seus contemporâneos para apanhar o vestígio que lhe ficara de cada um? No entanto, quanto não conversei com ele!" (p.170).

Latitude, vol. 4, no 2, pp. 67-89, 2010. 
Um homem plural e seu(s) tempo(s): revisitando Nabuco e as controvérsias em torno a Minha Formação

Já estamos, é claro, num dos terrenos temáticos mais controversos das reflexões autobiográficas nabuquianas: seu "europeísmo", a fascinação pela riqueza de produções culturais historicamente acumuladas nos países europeus, em contraste com a suposta vacuidade, em termos de legado e imaginação estética e histórica, que grassaria nas terras quase virgens de civilização do Novo Mundo ${ }^{11}$. A referência à "moléstia de Nabuco", oriunda da pena epistolar de Mário de Andrade (Araújo, 2004: 6), tornou-se famosa como símbolo da reação de diversos movimentos intelectuais posteriores (a começar, é claro, pelo modernismo dos anos 20 e 30) à concepção de formação e cultivo do espírito abraçada pelo memorialista, a qual estaria, aos olhos de seus críticos, inteiramente calcada na assimilação e imitação de elementos da cultura europeia e na concomitante rejeição das tradições culturais do Brasil (na realidade, das tradições americanas de modo mais geral). Aos olhos destes movimentos, nenhuma passagem foi mais infame do que a seguinte, insistentemente citada nas discussões sobre o grande abolicionista brasileiro:

"na América falta à paisagem, à vida, ao horizonte, à arquitetura, a tudo que nos cerca, o fundo histórico, a perspectiva humana; e...na Europa nos falta a pátria, isto é, a fôrma em que cada um de nós foi vazado ao nascer. De um lado do mar, sente-se a ausência do mundo; do outro, a ausência do país. O sentimento em nós é brasileiro; a imaginação, europeia. As paisagens todas do Novo Mundo, a floresta amazônica ou os pampas argentinos não valem para mim um trecho da Via Appia, uma volta da estrada de Salerno a Amalfi, um pedaço do cais do Sena à sombra do velho Louvre" (p.58-59).

Criticando as manifestações mais simplistas de ojeriza "nativista" ou "nacionalista" ao comentário de Nabuco, tais como o epíteto de "alienado" que lhe dirigiu Darcy Ribeiro, Mello nos lembra que a descrição, presente em Minha Formação, do dilema subjetivo vivido por Nabuco não consiste em um documento da vivência idiossincrática de um "alienado", mas em uma das mais vívidas vias de acesso à compreensão de uma experiência cultural que era bastante difundida dentre os membros das elites americanas, não apenas no Brasil como também em uma pletora de

11 Nabuco se define como cosmopolita e não como europeísta, mas o fato de que o seu cosmopolitismo é europeísmo fica evidente em frases como esta: "nossa imaginação não pode deixar de ser europeia, isto é, de ser humana" (p.58). Ou esta outra, de sabor hegeliano: "no século em que vivemos, o espírito humano, que é um só e terrivelmente centralista, está do outro lado do Atlântico" (p.59). Invertendo uma formulação do seu crítico Mário de Andrade, poderíamos dizer também que, para Nabuco, há uma Civilização, não civilizações. 
Gabriel Peters

outros contextos nacionais ${ }^{12}$ (Mello, 2000: 24-25). É importante ressaltar também que passagens como a anteriormente citada somente podem soar como sintomas de uma eurofilia incondicional se lidas fora de contexto, uma vez que Minha Formação, considerada in toto, oferece uma visão significativamente nuançada do vínculo de Nabuco com a Europa. Como afirma Ricardo Benzaquen de Araújo:

"mesmo quando se refere especificamente à sua juventude, nosso autor nunca deixa de nuançar essa preferência pela cultura europeia, contrabalançando-a com uma preocupação tão intensa com os destinos da 'pátria' que ele efetivamente parece se associar, na formulação de Costa Lima, ao 'drama existencial dos que se sentem comprometidos com o país, mas, ao mesmo tempo, nele não se integram ${ }^{\prime \prime 13}$ (2004: 6).

12 Para ficar apenas no exemplo brasileiro mais famoso dessa experiência, podemos lembrar o clássico ensaio machadiano sobre o "Instinto de Nacionalidade", que se exprime em termos muito similares aos de Nabuco ao defender que a proveniência nacional do escritor deve se manifestar sob a forma de "um sentimento íntimo" (Assis, 1955: 135) e não, por exemplo, da escolha de temáticas locais. Quanto aos recursos culturais e estéticos que deveriam alimentar a imaginação dos escritores brasileiros, Machado de Assis também reconhecia a necessidade inevitável de se guiar pelo "influxo externo", já que não haveria em nosso espaço intelectual, naquele momento, "a força necessária à invenção de doutrinas novas" (Santiago, 2004: 17). Como bem lembrou Carvalho, a confissão nabuquiana de sua contínua dualidade e instabilidade, de "sua incapacidade para se satisfazer exclusivamente na Europa e no Brasil", constitui um esboço de uma "sociologia dos intelectuais periféricos" (2004: 228), tematizando questões espinhosas e tremendamente atuais acerca da relação (efetiva e/ou desejada) dos intelectuais na periferia com as ideias emanantes do(s) "centro(s)", se me for permitido colocar a questão nesses termos simplistas. Muitas dessas discussões se desenrolam hoje nos termos do vocabulário da moda cunhado por interdisciplinas como os chamados "estudos culturais" e "estudos pós-coloniais", mas alguns comentadores tomam explicitamente o texto clássico de Nabuco como ponto de partida histórico-intelectual para pensar essa problemática (Santiago, 2004).

${ }^{13}$ Vários estudiosos apontam para o fato de que, vivendo em Washington "após tantos anos de exterior", Nabuco foi acometido de uma forte "sensação de desenraizamento" (Mello, 2005b: 156). Sintomática dessa sensação foi uma variação, anotada em seu diário, sobre o mesmo tema do sentimento brasileiro/imaginação europeia, em que a ênfase recai sobre o primeiro fator: "O espírito [imaginação] deve ter asas, o coração [sentimento] não as pode ter" (2005b: 156). Creio que outra variação deste tema nos foi fornecida, ironicamente, pelo próprio Mário de Andrade, quando este se definiu como "mais brasileiro que nacionalista" (apud Merquior, 1983: 137), uma autocaracterização que Nabuco provavelmente não teria problemas em tomar para si.

Latitude, vol. 4, no 2, pp. 67-89, 2010. 
Um homem plural e seu(s) tempo(s): revisitando Nabuco e as controvérsias em torno a Minha Formação

Suspeito que parte dos motivos da acusação de "alienação" dirigida a Nabuco está relacionada à sua fascinação confessa diante do mundanismo aristocrático, o que levaria alguns a percebê-lo apenas como uma espécie de "cosmopolita de salão". O fato, no entanto, é que uma leitura mais atenta de Minha Formação indica que a sensibilidade cosmopolita foi um elemento constitutivo do seu pensamento e atuação políticos. Cultivada desde cedo, mesmo antes de sua "grande viagem" ao velho mundo, no contato com membros do corpo diplomático em Petrópolis e na Corte, esta sensibilidade é apresentada por ele, em primeiro lugar, como uma escola de tolerância, um valor que José Veríssimo destacou, com razão, como "um dos fundamentos" de sua "filosofia prática" (1977: 97), estando na base de sua rejeição do republicanismo de matriz francesa ${ }^{14}$. A orientação cosmopolita também teria feito do autor pernambucano um político singular, profundamente atraído pela política "com ' $\mathrm{P}$ ' grande, isto é, da política que é história" (p.53) e parte "do drama humano universal" (p.54), enquanto infenso, por outro lado, à pequena política local dos "preconceitos e paixões de partido" (p.89). Nabuco confessa: "Politicamente, receito ter nascido cosmopolita" (p.55). E vai além, valendo-se de metáforas teatrais que evidenciam o viés estetizante de seu pensamento ético-político:

"Sou antes um espectador do meu século do que do meu país; a peça é para mim a civilização, se está representando em todos os teatros da humanidade...uma ligação mais íntima faz que a cena, quando se passa no Brasil, tenha para mim importância especial, mas isto não se confunde com pura emoção intelectual; é um prazer ou uma dor...que interessa o coração; não é um grande espetáculo, que prende e domina a inteligência. A Abolição no Brasil me interessou mais do que todos os outros fatos ou séries de fatos de que fui contemporâneo; a expulsão do Imperador...(e) a última revolta, quando se ouvia o canhão da guerra civil no mar e o silêncio ainda pior do terror em terra. Em tudo isto...há muito pouca política...o que há é a ação do drama humano universal de que falei, transportado para nossa terra" (p.54).

O influxo cosmopolita também está, é claro, na raiz do seu abolicionismo, a "única ideia" pela qual Nabuco julgava que passaria à história da política no Brasil ${ }^{15}$,

${ }^{14}$ Se "a intolerância é uma fobia da liberdade e do mundo" (p.62), a apologia nabuquiana da tolerância constitui um corolário de sua apologia da liberdade.

${ }^{15}$ A monomania de Nabuco em política tinha também um símile sociológico, qual seja, a tese, desenvolvida em $O$ Abolicionismo, de que a instituição da escravidão constituía o fator fundamental na compreensão da formação histórica do Brasil: "Nessa perspectiva, a escravidão não constitui um fenômeno a mais, inegavelmente relevante mas devendo ser levado em conta em igualdade de condições com outros, como a monocultura ou a grande propriedade territorial. Segundo Nabuco, foi a 
Gabriel Peters

uma vez que sua "fidelidade monárquica" poderia ser tida como um ato de gratidão pela "libertação dos escravos" (p.57-58) - uma afirmação que soa no mínimo exagerada, considerando-se o espaço que Nabuco dedica, no mesmo livro, a uma argumentação sobre as vantagens da monarquia em relação à república. Nos idos de 1877, Nabuco já havia descrito a escravidão como uma "nódoa que nos envergonha aos olhos do mundo" (Alonso, 2007: 69). Retornando ao tema na sua autobiografia, ele elenca precisamente o sentimento de humilhação diante da opinião pública internacional como um dos fatores históricos decisivos para a vitória da causa antiescravagista (p.189). Outros exemplos do impulso cosmopolita por trás de sua luta política poderiam ainda ser mencionados: os vínculos com a British and Foreign AntiSlavery Society (Alonso, 2007: 116) ou sua visita ao papa Leão XIII, descrita no antepenúltimo capítulo como parte de seu esforço em recorrer à "opinião pública do mundo" para captar "o interesse da dinastia" e "acordar o sentimento do país" para a questão, pertinente à política com "P" maiúsculo, isto é, uma questão que "era da humanidade toda e não apenas nossa" (p.214).

Para concluir essa seção com uma breve digressão, gostaria de sublinhar que a discussão do movimento abolicionista no livro confirma, de certo modo, a assertiva de Gilberto Freyre segundo a qual em Minha Formação está pintada "apenas parte de uma grande vida" (p.11). O mesmo Freyre nota, de passagem,o fato de que a participação de Nabuco na campanha da Abolição, sua maior realização como homem público, foi relembrada em apenas dois capítulos, e ainda assim "de um modo um tanto abstrato" (p.15). Vale a pena lembrar, a edição recente dos Diários de Nabuco demonstra que os oito anos (1879-1888) em que ele esteve na vanguarda do movimento abolicionista foram também aqueles em que o registro pessoal de impressões e vivências dos eventos à sua volta se tornou mais ralo e menos frequente.

Isto dá ensejo à hipótese de que a riqueza evocativa variável das memórias de Nabuco dependeu parcialmente do maior ou menor volume de notas íntimas que emanaram de sua pena nos diferentes momentos de sua vida, seja em função da maior fixação mnemônica permitida pelo processo da escrita, seja em função do uso documental ulterior que Nabuco possa ter feito das anotações em seus diários. $\mathrm{O}$ fato de que o seu mergulho de corpo e alma na luta pela libertação dos escravos o tenha deixado pouco tempo e/ou disposição para o registro rotineiro de suas experiências forçou-o a rememorar sua participação na campanha a certa distância temporal, e "o período transcorrido entre os eventos e a sua narração induz o autor a vê-los sobretudo em termos de tendências de longo prazo, expurgando a peripécia [as microconcatenações de eventos, os sucessos cotidianos] que para o político constitui o decisivo para explicar a trama em que participa" (Mello, 2005b: 243-244).

escravidão que formou o Brasil como nação, ela é a instituição que ilumina nosso passado mais poderosamente que qualquer outra. A partir dela, é que se definiram entre nós a economia, a organização social e a estrutura de classes, o Estado e o poder político, a própria cultura" (Mello, 2000: 6).

Latitude, vol. 4, nํㅡㄹ pp. 67-89, 2010. 
Um homem plural e seu(s) tempo(s): revisitando Nabuco e as controvérsias em torno a Minha Formação

\section{Autobiografia e auto-exposição}

Gilberto Freyre, na introdução à edição utilizada para a confecção deste texto, compara Nabuco a Montaigne, mestre da autoexploração ensaística cuja vida, aliás, também envolveu a inserção prévia, por "vocação patrícia", na atuação política:

"Este livro, Nabuco parece o ter escrito, pensando com Montaigne, que já se dera bastante aos outros; e que tinha o direito e, talvez, o dever de, à base das experiências por ele já vividas, darse principalmente a si mesmo, contemplando-se, analisando-se, aperfeiçoando-se no seu modo interior de ser, escrevendo a história de sua própria vida ou da sua própria pessoa sem temer a acusação de narcisismo da parte de críticos mais ou menos levianos'" (p.13).

No entanto, está claro que o estilo informal e desembaraçadamente intimista do velho Montaigne se afasta bastante do tom eloquente mantido por Nabuco quando fala de si mesmo, diferença notada por Merquior:

"Nabuco é sempre, como notou Graça Aranha, um escritor eloquente: é pouco ou nada intimista. Até em trechos de reminiscências autobiográficas..., seu subjetivismo...exibe um ego meio impessoal, radicalmente estranho ao eu desarrumado e nu das confissões genuínas [e.g, Montaigne]. Não se trata de uma diferença de autenticidade, e sim da distinção entre a literatura em primeira pessoa dos escritores públicos e a voz, naturalmente mais intima, dos autores solitários" (Merquior, 1977: 189).

De modo algo similar ao que acontece com Simmel, "cuja primeira e mais forte impressão" sobre seus contemporâneos foi "aquela da cátedra" (Waizbort, 2000: 571) antes que a dos escritos, foi também como orador, neste caso no parlamento, que Nabuco se destacou primeira e talvez predominantemente aos olhos de seus companheiros de época, destaque documentado em diversos depoimentos dos que puderam vê-lo e ouvi-lo16. Se nos fiarmos pelo já citado Graça Aranha, podemos perceber que é precisamente o estilo da oratória que continua a guiar a pena memorialística de Nabuco:

“...Nabuco, nas suas melhores páginas, fala, discorre para um auditório imediato. Há sempre alguém diante dele, e quando não é a multidão ou a assembleia, é um pequeno grupo de amigos.

16 Alguns estão coligidos em obra sobre a literatura brasileira dirigida por Afrânio Coutinho (1959: 267- 270). 
Gabriel Peters

Nas suas próprias 'confissões' não se recolhe ao confessionário, à sombra de uma nave deserta. Confessa-se de uma tribuna ou de uma cadeira oracular"17 (Aranha, 1942: 45).

A questão, como de costume, não pode ser tratada de modo simplista. Gilberto Freyre destaca que o nível de autoexposição presente em Minha Formação, tão pouco intimista para uma apreciação contemporânea, foi considerado escandaloso para alguns dos leitores de sua época (p.10), antes de também criticar Nabuco não por revelar-se em demasia, mas, ao contrário, por não fazê-lo suficientemente, quase excluindo de suas reflexões autobiográficas o registro dos aspectos mais privados ("o registro de alguma de suas explosões de cólera, de alguma das suas brigas de família, de algum dos seus jantares íntimos, de algum dos seus pecadilhos de sexo" [p.18]) e banais de sua existência. Freyre chega a sustentar que "a grande deficiência de Minha Formação" consiste na ausência de revelações pessoais que pudessem fazer Nabuco "parecer ridículo aos olhos dos leitores" (p. 17).

Em defesa de Nabuco, talvez valha a pena ressaltar que diversas passagens do livro revelam uma tremenda coragem de autoexposição. O exemplo mais óbvio é a confissão do seu fracasso como poeta (p.76-89), que chega ao ponto de incluir evidências da insinceridade dos elogios que seu livro de poemas da primeira metade dos anos 1870, Amour et Dieu, recebeu do seu ídolo literário francês Ernest Renan. Este, após qualificar os versos de Nabuco como "excelentes", confessou, em uma "traidora página", seu costume bem intencionado de mentir sobre a qualidade de versos que recebia de "jovens poetas", de modo a não "apunhalá-los" (p.80).

$\mathrm{O}$ estudo de outras fontes sobre nosso autor revela que Nabuco pareceu vivenciar, durante a maior parte de sua vida, o conflito interno entre a tentação poética e o juízo desencantado sobre o próprio talento. Com apenas 15 anos, após receber elogios circunspectos de Machado de Assis a respeito de uma poesia declamada em um sarau literário, ele manda sua primeira carta ao futuro amigo dizendo:

"Não sou poeta; as minhas toscas composições...ainda não pretendem a tanto; o título pomposo de - poeta - que, por extrema bondade, e complacência, dignou-se me a aplicar, poderia, esmagando a minha nula valia, encher-me de um orgulho sem fundamento, que me elevasse acima do que eu realmente sou, se porventura não tivesse a indestrutível conviç̧ão de que ele verdadeiramente não me pertence... De uma certa idade em diante pretendo não me aplicar mais à poesia...Quando as minhas

\footnotetext{
${ }^{17}$ Nesse sentido, não deixa de ser um sintoma da importância da oratória no estilo de Nabuco o fato de que, dentre os livros "mundanos" que levaria consigo para o confinamento numa ilha deserta, ele tenha escolhido as cartas do grande orador (e, ironicamente, mártir republicano) Cícero (p.76).
}

Latitude, vol. 4, nº 2, pp. 67-89, 2010. 
Um homem plural e seu(s) tempo(s): revisitando Nabuco e as controvérsias em torno a Minha Formação

faculdades concentradas pelo estudo e pela meditação se puderem aplicar ao positivo, e ao exato, deixarei de queimar incenso às musas do Parnaso, para me ir alistar na fileira dos mais medíocres apóstolos do positivismo" (apud Aranha, 1942: 90).

Nabuco não deixaria de queimar incenso às musas do Parnaso tão cedo e, melhor ainda, jamais se tornaria um medíocre apóstolo do positivismo. Minha Formação, entretanto, de fato traz, na pena do próprio Nabuco, o juízo que seria feito dele pela posteridade: era escritor (escritor historiador e escritor memorialista), mas não poeta. Não possuía "a forma do verso" (p.83), do que resultava que "naufragaria sempre" nos seus empreendimentos de versejador (p.84). O curioso é que, mesmo no que diz respeito aos próprios juízos de Nabuco sobre seu talento poético, nem todas as opiniões emitidas no livro parecem haver sido definitivas. Por exemplo, ele afirma neste que o drama em verso francês acerca do problema da Alsácia-Lorena que ele havia iniciado em 1875 tinha como "única qualidade" o fato de "ser inédito" (p.93), mostrando-se ainda arrependido por haver "infligido" a leitura do mesmo a um grupo seleto de amigos. Um juízo tão severo sobre os méritos de tal obra nos faz pensar que Nabuco a abandonaria para sempre, mas eis que surge uma carta de 1908 em que o embaixador informa ao colega da Academia Machado de Assis:

"Ocupei-me muito ultimamente com a revisão de um drama em verso francês que escrevi há trinta anos. $O$ assunto, como $V$. talvez se lembre, é a conquista, ou antes o desmembramento, da Alsácia-Lorena...Estou muito contente da obra depois da revisão e da mudança do final. Antes parecia-me mal acabada" (apud Aranha, 1942: 163).

O drama em verso está, em grande medida, esquecido. No entanto, é irônico constatá-lo, a obra em que Nabuco confessou tão abertamente não ter nascido artista e não possuir a forma do verso será justamente aquela que mais lhe consagrará como artista literário.

\section{Equilíbrio, contradições e ambiguidades}

Sob diferentes formas e com ênfases distintas, diversos autores e escolas de pensamento na teoria social e na filosofia já questionaram o pressuposto de que as subjetividades humanas são internamente coerentes e integradas, o que significaria negligenciar o fato de que qualquer sujeito comporta uma pluralidade de dimensões intra-subjetivas, as quais apresentam, ainda que em graus variáveis, inconsistências, tensões e conflitos entre si. É curioso notar que, em maio de 1877, o próprio Nabuco registrou em seu diário sua anuência à tese psicológica a que contemporaneamente nos 
Gabriel Peters

referimos como a de um "self múltiplo" (Jon Elster) ou do "homem plural" (Bernard Lahire):

"Nenhum erro é mais comum do que supormos que cada pessoa tem um caráter decidido, que há de proceder de um modo certo, sentir como nós prevemos, e que enfim é uma unidade. Essas pessoas não existem. O erro contrário é preferível como regra de indução, supor que cada um tem em si elementos divergentes, opostos e irreconciláveis" (2005a: 146)

Diferentemente do jovem adido de legação, o Nabuco maduro que retraça reflexivamente sua própria trajetória já não parece tão disposto a aceitar a irreconciliabilidade dos diferentes componentes de sua Weltanschauung. Ao contrário, a construção narrativa de Minha Formação evidencia sua pretensão de demonstrar como tais componentes se encaixam harmoniosamente. Seja como for, o nível de integração e coerência entre os distintos elementos da personalidade de Nabuco e, mais especificamente, entre os ingredientes de sua visão de mundo (e.g, o catolicismo, a "impressão aristocrática da vida" [p.110], o compromisso com a libertação dos escravos, a defesa da monarquia) tem sido uma temática frequente nas apreciações de sua obra, dando ensejo a opiniões radicalmente diversas sobre o tópico.

Sem disfarçar sua admiração, Mello afirmou, por exemplo, que "o traço decisivo" da personalidade de Nabuco consistiu na "inteligência como exercício do equilíbrio", uma característica "presente na sua vida pública e detectável...nas suas reações íntimas a acontecimentos e pessoas do seu tempo" (Mello, 2005a: 12). Em um texto de 1883, Sílvio Romero (que posteriormente mudaria de ideia sobre o autor de $O$ Abolicionismo) oferece algo como a contraparte negativa do elogio de Mello ao dizer, em seu tom caracteristicamente belicoso: “O Sr. Nabuco...é um hermafrodita da inteligência, isto é, vive atufado num dualismo terrível: todas as suas ideias têm duas facetas que se contradizem" (apud Montello, 1998: 212). Entre esses dois extremos, há um continuum de perspectivas que buscam compreender a complexa personalidade de Nabuco em termos de suas (ao menos aparentes) incoerências ou ambiguidades (por exemplo, Salles, 2002: 16).

Um primeiro contato perfunctório com Minha Formação talvez reforce essa sensação de estarmos diante de um espírito ambivalente, solicitado em direções diversas e aparentemente inconciliáveis. Como vimos, segundo a leitura do Nabuco maduro, a sua subjetividade foi efetivamente marcada, na juventude, por um enorme ecletismo espiritual (o "politeísmo da mocidade" [p.57]), mas ele tomaria para si, na maturidade, precisamente o ideal de um equilíbrio harmonioso e "apolíneo" (Gilberto Freyre) dos diferentes galhos do seu espírito. Em que medida esse equilíbrio é alcançado no texto (ou no homem mesmo!) é questão aberta, obviamente, mas o que vale ressaltar é que diversos eixos temáticos de Minha Formação podem ser lidos tanto naquela chave interpretativa mais benevolente ou "evaldiana", propensa a escavar os

Latitude, vol. 4, no 2, pp. 67-89, 2010. 
Um homem plural e seu(s) tempo(s): revisitando Nabuco e as controvérsias em torno a Minha Formação

habilidosos artifícios argumentativos pelos quais Nabuco equilibraria os diferentes ingredientes de sua formação, quanto em uma chave mais crítica, tendente a identificar ambigüidades ou, à la limite, contradições internas na visão de mundo nabuquiana.

Segundo esta última lente de leitura, pareceria estranho, $a b$ initio, o fato de o livro ser aberto com o elogio ao reformismo de seu pai, um liberal convertido que teria comandado, no período imperial, o movimento político que ia "da velha experiência para a nova experimentação" (p.31). A estranheza decorreria da circunstância de que toda a tônica de Minha Formação consiste precisamente em uma reação àqueles que queriam substituir uma orientação calcada na experiência histórica (a "velha experiência" do Império) pela construção de um novo Brasil fundado sobre princípios abstratos (a "nova experimentação" republicana que vigia na década de 1890). Por outro lado, seguindo a primeira grade interpretativa, poderíamos replicar, àqueles que acusam Nabuco de inconsistência, que um dos princípios de sua "geometria política" (p.52) consistia precisamente na defesa do equilíbrio, empiricamente alcançado pela experiência inglesa, entre, de um lado, o "espírito de reforma" e, de outro, o respeito à tradição como garantia da estabilidade política, como proteção diante da ameaça de degeneração da democracia em demagogia, e do reformismo em revolucionarismo. $\mathrm{O}$ debate poderia se prolongar...

Mais delicada, ao menos à luz de uma leitura retrospectiva, é a presença de uma forte "impressão aristocrática da vida" em uma das principais figuras do movimento abolicionista, uma impressão cujo cultivo é descrito em maior riqueza de detalhes no livro do que sua participação na luta antiescravista. O fato de se mostrar como um abolicionista impregnado do ethos aristocrático, combinado ainda à sua corajosa confissão da "saudade do escravo" (p.183) e ao retrato da "espécie particular de escravidão" (p.184), fundada na simpatia mútua entre senhores e escravos, que haveria existido em propriedades mais antigas e "isolada(s) do mundo" como Massangana, fez com que Nabuco fosse acusado de ofensivamente condescendente e "destituído de semancol" por alguns leitores atuais (Moriconi, 2001: 170). Mesmo estes não chegam a supor, no entanto, que Nabuco tenha sido cego à violência da instituição em meio à qual cresceu, violência descoberta em uma famosa cena inesquecida de sua infância:

\footnotetext{
“...a escravidão para mim cabe toda em um quadro inesquecido da infância...Eu estava em uma tarde sentado no patamar da escada de casa, quando vejo precipitar-se para mim um jovem negro desconhecido, de cerca de dezoito anos, o qual se abraça a meus pés suplicando-me pelo amor de Deus que o fizesse comprar por minha madrinha para me servir. Ele vinha das vizinhanças, procurando mudar de senhor, porque o dele, dizia-me, o castigava, $e$ ele tinha fugido com risco de vida...Foi este traço inesperado que me descobriu a natureza da instituição com a qual eu vivera até então familiarmente, sem suspeitar a dor que ela ocultava" (p.182).
} 
Gabriel Peters

Minha impressão é que, no capítulo sobre Massangana, Nabuco reportou, com o benefício da visão retrospectiva e do sentimento de saudade do escravo "que muito espantaria um Garrison ou um John Brown" (p.183), sua intuição da complexa ambiguidade das relações entre senhores e escravos nos engenhos nordestinos, ambiguidade similar àquela que Gilberto Freyre, anos depois, se esforçaria por retratar. Veja-se, por exemplo, a descrição que este faz das relações entre senhores e escravas:

\begin{abstract}
"Vencedores no sentido militar e técnico sobre as populações indígenas; dominadores absolutos dos negros importados da Africa para o duro trabalho da bagaceira, os europeus e seus descendentes tiveram entretanto de transigir com indios e africanos quanto às relações genéticas e sociais. A escassez de mulheres brancas criou zonas de confraternização entre vencedores e vencidos, entre senhores e escravos. Sem deixarem de ser relações - as dos brancos com mulheres de cor - de 'superiores' com 'inferiores' e, no maior número de casos, de senhores desabusados e sádicos com escravas passivas, adoçaram-se, entretanto, com a necessidade experimentada por muitos colonos de constituírem família dentro dessas circunstâncias e sobre essa base" (Freyre, 2006: 33).
\end{abstract}

Não pretendo superestimar, todavia, as similitudes de visão entre os dois pernambucanos no que toca a essa questão. Ambos partilham a intuição da existência de uma espécie desafiadoramente ambivalente de cumplicidade na violência, e de violência na cumplicidade (vale enfatizar, para que a ambigüidade não seja diluída), operante nas relações escravistas na sociedade brasileira - ou, pelo menos, em algumas dentre estas, como tempera Nabuco. Não obstante, o tema da gestação sócio-histórica de "zonas de confraternização" entre senhores e escravos não apenas é desenvolvido muito mais diligentemente no pensamento de Gilberto Freyre, como também assume na pena deste inflexões completamente ausentes nas reflexões memorialísticas de Nabuco. Como a passagem supracitada de Casa Grande e Senzala permite entrever, o primeiro se diferencia do último pelo "enorme destaque concedido ao papel desempenhado pelas paixões - sobretudo as de natureza sexual - na geração de uma atmosfera de intimidade e calor que, sem descartar os antagonismos, tornava possível sua convivência" (Araújo, 2009: 202; ver também Araújo, 2005). Além de estar enlaçado, é claro, à preocupação bem mais pronunciada do mestre de Apipucos com o tema da mestiçagem, o foco sobre as paixões também ensejou a Freyre caracterizar de modo ainda mais vívido e dramático a confraternização dos opostos, os "antagonismos em equilíbrio" que compunham o Brasil patriarcal e escravista. Em contraste, tal realce do passional não apenas é alheio à discussão de Nabuco como restaria imensamente deslocado em um retrato como o que ele pinta de Massangana, todo ornado com

Latitude, vol. 4, no 2, pp. 67-89, 2010. 
Um homem plural e seu(s) tempo(s): revisitando Nabuco e as controvérsias em torno a Minha Formação

motivos e alusões religiosas - culminando na sua assimilação implícita do escravo, qua sofredor magnânimo, à figura do Cristo (sua versão particular de uma alegoria que, de resto, havia sido amplamente veiculada pela militância abolicionista [ver Alonso, 2007]):

"Oh! Os santos pretos! Seriam eles os intercessores pela nossa infeliz terra, que regaram com o seu sangue, mas abençoaram com o seu amor!...raça generosa, entre todas que a desigualdade da sua condição enternecia, ao invés de azedar e, por sua doçura no sofrimento, emprestava até mesmo à opressão de que era a vítima um reflexo de bondade..." (p.188).

Seja como for, a sutileza e a complexidade das argumentações de Nabuco e Freyre são muitas vezes perdidas de vista em virtude do estranhamento, ou até mesmo do choque, vivenciado por leitores contemporâneos diante da alusão nabuquiana à saudade do escravo ou da referência freyriana ao "adoçamento" do escravismo no Brasil. Em favor de Nabuco e Freyre, não para isentá-los da crítica, mas para estimular uma leitura justa dos mesmos, só se pode recomendar: a) o compromisso com a sensibilidade histórica, isto é, a sensitividade à multiplicidade de formas históricas de ação e experiência humana, relacionada à percepção correlata dos perigos do etno e do cronocentrismo, bem como do que Oakeshott chamava de "política retrospectiva"; b) o dever do máximo realismo possível, em função do qual é obrigação do historiador e do memorialista retratar um fenômeno social e psicologicamente ambivalente como tal ${ }^{18}$.

\section{À guisa de conclusão: o olhar da maturidade sobre a juventude...e o dedo da Providência}

No momento em que Minha Formação foi publicado, o espírito de Nabuco já havia adquirido "a aspiração da forma e do repouso definitivo" (p.240). É esse espírito sereno, estável e apolíneo que se debruça sobre o jovem dinâmico, instável e hiperestimulado (sensorial, estética e intelectualmente) que ele foi um dia. Dentre as facetas mais características da sua mocidade estava precisamente a curiosidade febril e

18 Os temas mencionados não são os únicos a aparecerem nas discussões sobre a consistência interna das opiniões de Nabuco. José Veríssimo, um comentador bastante simpático, julga suas convicções liberais e católicas incompatíveis entre si: “Convencidamente persuadido da incompossibilidade absoluta do liberalismo com o catolicismo, não acho no meu espírito elasticidade bastante para entender a composição que faz o Sr. Nabuco das suas crenças católicas com o seu liberalismo orgânico e irredutível...O Sr. Joaquim Nabuco é seguramente um espírito religioso; que seja um espírito católico, tenho dúvidas...E por isso ele pôde, com pureza insuspeitável, crer-se liberal e católico, admitir Renan e São Tomás, tentando de boa fé para seu uso uma aliança que o papado já condenou" (Veríssimo, 1977: 97). 
Gabriel Peters

inconstante, primeiramente apresentada em uma confissão da sua "promiscuidade" intelectual dos tempos de Academia:

"As minhas ideias eram...uma mistura e uma confusão; havia de tudo. Ávido de impressões novas, fazendo os meus primeiros conhecimentos com os grandes autores, com os livros de prestígio, com as idéias livres, tudo o que era brilhante, original, harmonioso, me seduzia e arrebatava por igual. Era o deslumbramento das descobertas contínuas, a eflorescência do espirito: todos os seus galhos cobriam-se espontaneamente de rosas efêmeras" (p.33)

Essa experiência de fascinação indiscriminada, oscilante e insaciável marcou não apenas sua relação com os livros e autores, mas se manifestou, também, na sua vacilação entre a adesão à República ou à Monarquia e, principalmente, na forma como vivenciou sua primeira viagem à Europa (caps. 4 e 5), apresentada pelo Nabuco maduro como uma busca frenética de contatos com personalidades célebres, lugares, monumentos culturais e o que quer que pudesse arrancar "um grito de admiração a um viajante inteligente" (p. 56) - o Nabuco moço, de passagem pela Europa, até poderia tomar como sua uma passagem de Fernando Pessoa: "Tudo me interessa e nada me prende" (Pessoa, 2006: 49). Não me alongarei sobre as considerações que o Nabuco da casa dos 40 faz sobre sua própria psicologia quando rapaz, uma vez que elas já foram objeto de uma detalhada e erudita investigação por Ricardo Benzaquen de Araújo (2004), que encontra interessantes similaridades entre o instável, curioso e hiperestimulado Nabuco da juventude e as descrições do "homem das multidões" por Edgar Allan Poe, da atitude blasé por Simmel e do melancólico segundo a teoria aristotélica dos humores ${ }^{19}$.

Nabuco voltaria à vida pública pela via da diplomacia, mas o estado de espírito "fleumático" e o sentimento religioso o acompanhariam até o fim. Depois de renunciar alegremente aos seus discursos anticlericais da juventude "em favor das

${ }^{19}$ Embebido do valor da serenidade e do repouso do espírito, o autor de Minha Formação reconta sua tournée pela Europa como uma "infernal sucessão" (Araújo, 2004: 7) de impressões culturais e estéticas vivenciadas en passant, sem o tempo e a disposição subjetiva devidos para que aquelas impressões ficassem propriamente gravadas em seu espírito: “De passagem, pode-se ver muita coisa, mas não se tem a revelação de nada. A primeira condição para o espírito receber a impressão de uma criação qualquer, seja ela de Deus, seja das épocas - nada é puramente individual - é o repouso, a ocasião, a passividade, o apagamento do pensamento próprio; dar à forma divina o tempo que ela quiser para refletir-se em nós, para deixar-nos compreendê-la e admirá-la, para revelar-nos o pensamento originário donde nasceu" (p.65-66).

Latitude, vol. 4, nํㅡㄹ pp. 67-89, 2010. 
Um homem plural e seu(s) tempo(s): revisitando Nabuco e as controvérsias em torno a Minha Formação

traças que os consumiram" ${ }^{20}$ (p.51), permaneceu cingido à crença que foi a de seu pai e a de seu mestre (seu "Sócrates": o Barão de Tautphoeus) e entrou "no bosque das Musas" levando "o silêncio e a tranquilidade na alma" (p.87). Nabuco passou também a ver nos eventos o toque da Providência Divina. Isto permitiu a ele consolar-se da queda da monarquia:

“O 15 de Novembro não é uma queda, é uma assunção...É a ordem do destino para que a dinastia brasileira fosse arrebatada, antes de começar seu declínio, antes de correr o risco de esquecer a sua tradição" (p.206).

Como vemos nos seus Diários, a crença na Providência também lhe estimulou a desenvolver pitorescas reflexões filosóficas a propósito de ratos, morcegos e pavões, as quais parecem saídas de algum personagem de Machado:

"Não sei de ponto de vista algum explicar a criação de certos animais, como o rato e o morcego...Que foram composições propositais não tenho dúvida. O pavão é um desenho, uma imaginação de pintor. Não se imagina um pavão aparecendo ao acaso na natureza mais do que numa tela. É uma ideia, que o precede, e não está nele, nem nas partes que o compõem, nem em nada que o cerca. O homem compreende-se, como o pavão" (2005b: 206).

Falando em Machado de Assis, é precisamente em uma carta a este que encontramos o mais emocionante exemplar de interpretação "providencial" fornecida pelo Nabuco maduro, carta com que o embaixador tenta consolar seu amigo diante do falecimento de sua esposa Carolina. É com esta passagem dolorosa, passível de ser vista também como dolorosamente machista, que decidi encerrar este texto. Se um motivo menos arbitrário que a emoção pessoal for necessário para justificar a escolha de tal citação nabuquiana, podemos vê-la como mais um exemplo da lente através da qual Nabuco passou a ver o mundo ao final de sua longa formação:

"Que the hei de dizer? Morrer antes de V. foi um ato de misericórdia que a Providência dispensou a Dona Carolina. A viúva sofre sempre mais, às vezes tragicamente. No seu caso a imaginação, o interesse intelectual, o trabalho é um ambiente que permite em parte à dor a evaporação excessiva. A solução do dilema

${ }^{20}$ Ele alude, convenientemente, a uma passagem do Novo Testamento: “Não ajunteis tesouros na terra, onde a traça e a ferrugem tudo consomem, e onde os ladrões minam e roubam" (Mateus, 6: 19). 
Gabriel Peters

inevitável foi a melhor para ambos: coube a $V$. o sofrimento, V.compreenderá que o vácuo do coração precisa ser compensado pelo movimento e pela agitação do seu espírito. Será este o seu conforto e a maior dívida da nossa língua para com o túmulo a cuja sombra V. vai se acolher" (apud Aranha, 1942: 132)21.

\section{Bibliografias}

ASSIS, Machado de. (1955), "Instinto de nacionalidade". In: Crítica literária. São Paulo, W.M.Jackson Inc.

ALONSO, Angela. (2007), Joaquim Nabuco. São Paulo, Companhia das Letras.

ARANHA, Graça (Org.). (1942), Machado de Assis e Joaquim Nabuco: correspondência. Rio de Janeiro, F. Briguiet \& Cia.

ARAÚJO, Ricardo Benzaquen de. (2004), “Através do espelho: subjetividade em Minha Formação, de Joaquim Nabuco". Revista Brasileira de Ciências Sociais, 19: 56, pp.5-13.

(2005), Guerra e paz. Casa Grande \& Senzala e a obra de Gilberto Freyre nos anos 30. São Paulo, Editora 34.

(2009), “'Chuvas de verão'. Antagonismos em equilíbrio em Casa Grande ESenzala, de Gilberto Freyre". In: Botelho, André \& Shwarcz, Lilia Moritz. Um enigma chamado Brasil. São Paulo, Companhia das Letras.

CARVALHO, Maria Alice Rezende de. (2001), "Joaquim Nabuco: Minha Formação". In: L.Dantas Mota (org.). Introdução ao Brasil: um banquete no trópico. São Paulo, Senac, pp.219-236.

COUTINHO, Afrânio. (1959), A literatura no Brasil - Vol.3, Tomo 1. Rio de Janeiro, São José.

FREYRE, Gilberto. (1998), Introdução. In: NABUCO, Joaquim. Minha Formação. Brasília, Senado Federal.

(2006), Casa-Grande e senzala. São Paulo, Global.

MELLO, Evaldo Cabral de. (2000), “Joaquim Nabuco". Revista Tempo Brasileiro, 140.

MERQUIOR, José Guilherme. (1977), De Anchieta a Euclides: breve história da literatura brasileira. Rio de Janeiro, José Olympio.

(1983), O elixir do apocalipse. Rio de Janeiro, Nova Fronteira.

MILLS, Charles Whright. (1975), A imaginação sociológica. Rio de Janeiro, Zahar.

MONTELLO, Josué. (1998), Os inimigos de Machado de Assis. Rio de Janeiro, Nova Fronteira.

${ }^{21}$ Não teria sabido da existência de tão pungente carta não fosse pela erudição generosa do meu amigo e (sempre) mestre Luís de Gusmão.

Latitude, vol. 4, no 2, pp. 67-89, 2010. 
Um homem plural e seu(s) tempo(s): revisitando Nabuco e as controvérsias em torno a Minha Formação

MORICONI, Ítalo. (2001), “Um estadista sensitivo: a noção de formação e o papel do literário em Minha Formação, de Joaquim Nabuco". Revista Brasileira de Ciências Sociais, 16: 46 , jun.

NABUCO, Joaquim. (1998a), Um estadista do império. Rio de Janeiro, Topbooks. (1998b). Minha Formação. Brasília, Senado Federal, 1998. (2005a), Diários. Volume 1: 1873-1888. Rio de Janeiro/Recife, Bem-Te$\mathrm{Vi} /$ Massangana.

(2005b), Diários. Volume 2: 1889-1910. Rio de Janeiro/Recife, Bem-Te$\mathrm{Vi} /$ Massangana.

PESSOA, Fernando. (2006), Livro do desassossego. São Paulo, Companhia das Letras.

SALLES, Ricardo. (2002), Um pensador do Império. Rio de Janeiro, Topbooks.

SANTIAGO, Silviano. (2004), O cosmopolitismo do pobre. Belo Horizonte, UFMG.

VERÍSSIMO, José. (1977), Estudos de literatura brasileira (Vol.3). São Paulo, USP.

WAIZBORT, Leopoldo. (2000), As aventuras de Georg Simmel. São Paulo, 34. 